\title{
Physicochemical characterization and comparison of labels of beef bouillon cubes
}

\author{
Anderson Maciel de VASCONCELOS ${ }^{1}$, Sandra Maria Lopes dos SANTOS ${ }^{1,2 *}$, Marlene Nunes DAMACENO ${ }^{1}$, \\ Antonio Belfort Dantas CAVALCANTE ${ }^{1}$
}

\begin{abstract}
This study aimed at determining the centesimal composition, the energy value and the sodium content in beef bouillon cubes and compare them with the nutritional information by the manufacturer. Beef bouillon cube samples were collected in supermarkets in of the city of Limoeiro do Norte/CE, and the levels of nutrients were determined by official analysis methods. The physicochemical analyses carried out were moisture, lipids, proteins, fixed mineral residue, total carbohydrates and sodium content. The beef bouillon cubes analyzed showed a low moisture content $(3.23-4.23 \mathrm{~g} / 100 \mathrm{~g})$ and high levels of lipids $(19.72-20.05 \mathrm{~g} / 100 \mathrm{~g})$ and fixed mineral residue $(53.24-57.61 \mathrm{~g} / 100 \mathrm{~g})$. When compared to the data reported on their labels, all the parameters were in smaller amounts than the ones declared in all analyzed brands. The average sodium content found in the samples ranged from 758.5 to $815.5 \mathrm{mg} /$ serving of the product. Considering that the results were based on a portion of broth and that these amounts are related to half a cube of beef bouillon, it becomes quite alarming the amount of sodium available in this type of product, since the food prepared with this ingredient is usually eaten alongside other foods, which also contain sodium in their composition.
\end{abstract}

Keywords: dehydrated food; nutritional composition; labeling.

Practical Application: This study highlights the importance of investigating nutrients in foods and verifying whether this information is consistent with the one reported on labels, once the consumer is entitled to correct and truthful information. The products chosen for analysis were beef bouillon cubes. The results indicate that the nutritional composition described on the labels differs from the results found in the laboratory, suggesting the necessity of a greater control by the industry and regulatory agencies.

\section{Introduction}

Beef bouillon cubes, as other forms of spices, are widely used as ingredients in food preparation, providing them with flavor and a better sensory perception by the consumers (Kim et al., 2017). Gupta \& Bongers (2011) classify beef bouillon cubes according to the ingredients present in their composition, varying mainly the flavor they are formulated with. They can have beef, poultry, vegetable flavors and others. On an industrial scale, the manufacturing process of the cubes consists in mixing ingredients (salt, monosodium glutamate, palm oil, caramel, spices such as soybean, locust bean gum, onion, tomato, natural proteins and starch), coloring and flavoring agents (Raw Materials Research and Development Council, 2003; Rodrigues et al., 2016).

The nutritional value of a food is related to the qualitative and quantitative composition of the nutrients present in it (Karšulínová et al., 2007). Among these, both lipid fraction and sodium content have an enormous relevance because they play important roles on the maintenance of human health (Visioli \& Galli, 1998). This and other information can be seen on the labels of food packages. Food labeling is regulated by the National Health Surveillance Agency. It is mandatory and essential because, upon informing the consumer of the types of nutrients and their amounts, it allows a better selection of foods considering their nutritional information, contributing to dietary control and indirectly enabling disease prevention (Brasil, 2003a). However, for this purpose, it is essential that the information provided on the labels be reliable.

Labeling regulation in Brazil was an important achievement for consumers. However, studies have pointed out some imperfections, especially ones regarding to nutritional information (Câmara et al., 2008; Lobanco et al., 2009) or discrepancies between the results displayed on the label and those found in foods when they are analyzed. Therefore, this study aimed at determining the centesimal composition, the energy value and the sodium content of beef bouillon cubes sold in Limoeiro do Norte, Ceará (CE), Brazil, and compare them with the nutrition label informed by the manufacturer. 


\section{Material and methods}

Beef bouillon cubes produced by the top three brands sold in supermarkets in Limoeiro do Norte district were evaluated. Three cubes of each brand were analyzed in duplicate, totaling 18 samples. The samples (A1, A2 and A3) were sent to the Food Biochemistry Laboratory of the Federal Institute of Education, Science and Technology of Ceará, campus Limoeiro do Norte, and stored in a cool and dry place until analysis.

The moisture and fixed mineral residue analyses were performed by the gravimetric method using direct drying at $105^{\circ} \mathrm{C}$ in an oven until constant weight to determine the first and carbonization of the samples in plates followed by incineration in a muffle furnace at $550{ }^{\circ} \mathrm{C}$ to obtain the last; the crude protein content was determined by the Kjeldahl method and the result was multiplied by 6.25 to convert the total Nitrogen into protein; the lipid content was obtained by extraction using hexane in a Soxhlet apparatus according to the Association of Official Analytical Chemists (Association of Official Analytical Chemists, 2005). The content of total reducing sugars was obtained by the DNS (3,5-dinitrosalicylic acid) method according to the methodology described by Miller (1959).

The concentration of sodium was determined by flame photometry after digestion of organic matter through wet pathway with nitric acid, according to the methodology described by Malavolta et al. (1997).

The total energy value (TEV) was obtained according to the system developed by Atwater (1910), which defines that $1 \mathrm{~g}$ protein provides on average 4 calories ( $4 \mathrm{kcal}$ ), $1 \mathrm{~g}$ fat provides on average 9 calories $(9 \mathrm{kcal})$, and $1 \mathrm{~g}$ of carbohydrate provides on average 4 calories $(4 \mathrm{kcal})$. However, for this study, protein concentrations were not considered for the calculation of energy value in order to facilitate a comparison with the labels, once they did not present results for that parameter.

The nutritional labels of products were recorded by photographing the packaging or using the information available on the company's website. Protein, lipid, carbohydrate and sodium contents were evaluated using both $100 \mathrm{~g}$ of product and one serving for comparison with the information provided in the Brazilian Table of Food Composition (Núcleo de Estudos e Pesquisas em Alimentação, 2011) and in the label of the products, respectively. According to the agreement made between the Brazilian Ministry of Health and food producers associations, the recommended serving product corresponds to the mass required to prepare $250 \mathrm{~mL}$ of bouillon (Brasil, 2003a).

The results were presented as means $\pm \mathrm{SD}$. Analysis of Variance (ANOVA) was used to assess this results and Tukey test to compare the averages $(\mathrm{p}<0.05)$ using the Statistica 7 software (Statsoft, 2007).

\section{Results and discussion}

The chemical composition of the beef bouillon cube samples is shown in Table 1. The samples showed a low moisture content and high levels of lipids and fixed mineral residue, the latter being similar in all three samples. The high lipids content in these samples came from the addition of vegetable fat in its composition, while the high mineral content can be justified because beef bouillon cubes contain a high concentration of flavor enhancers, salt and spices.

All analyzed parameters were higher than the values reported in the Brazilian Table of Food Composition (Núcleo de Estudos e Pesquisas em Alimentação, 2011), with the exception of crude protein and fixed mineral residue contents, whose variations were within the limits recommended in the Table above. Guimarães \& Lanfer-Marquez (2002) studied the chemical composition of beef bouillon cubes and found 8.20 and $8.57 \%$ of protein, values higher than those found in this study. The low protein content found in the samples, especially A1 $(1.68 \mathrm{~g} / 100 \mathrm{~g})$ and A3 $(2.39 \mathrm{~g} / 100 \mathrm{~g})$, may be a result of the amount of protein source used in the broth formulation, which is it possible to observe even in the labels, since in this all the ingredients must appear in descending order, of the respective proportion; in the analyzed samples, the beef appeared only from the seventh ingredient, with the salt appearing as the highest concentration component in all the samples.

It is important to observe that the information provided on the labels of beef bouillon cubes refer to the recommended serving to prepare $250 \mathrm{~mL}$ of bouillon. Therefore, the next results will be presented in function of this serving to facilitate a comparison with the data provided on the labels.

The protein concentrations found in the servings of beef bouillon cube samples (Table 2) were less than $0.5 \%$. Therefore, they are not considered significant by the legislation, allowing the nutritional information to be expressed as "zero", "0" or "does not contain" (Brasil, 2003b). The lipid and carbohydrate contents found analytically in bouillons were very close to those reported in the labels of the samples A1 and A3. However, the carbohydrate content found in the sample A2 was almost four times higher. We believe that there may have been a failure in preparing the label of this product since the results are very close to those found in other analyzed brands.

The average sodium content found in the samples ranged from 758.5 to $815.5 \mathrm{mg} / \mathrm{serving}$ of the product, corresponding, respectively, to 38 and $41 \%$ of the recommended daily intake. This is worrisome, as food prepared with this ingredient is usually eaten together with other foods containing salt in their composition. Ingestion of sodium is essential to health, but excess intake this mineral is a risk factor for hypertension and

Table 1. Centesimal composition of beef bouillon cubes of three brands and Brazilian Table of Food Composition (BTFC) reference values.

\begin{tabular}{lrcrr}
\hline \multicolumn{1}{c}{\begin{tabular}{c} 
Components \\
\multicolumn{1}{c}{$(\mathrm{g} / 100 \mathrm{~g})$}
\end{tabular}} & \multicolumn{1}{c}{ A1 } & \multicolumn{1}{c}{ A2 } & \multicolumn{1}{c}{ A3 } & \multirow{2}{*}{ BTFC } \\
\cline { 2 - 4 } & $4.23 \mathrm{a}$ & $3.78 \mathrm{ab}$ & $3.23 \mathrm{~b}$ & 2.90 \\
Moisture & $19.84 \mathrm{a}$ & $20.05 \mathrm{a}$ & $19.72 \mathrm{a}$ & 16.60 \\
Lipids & $1.68 \mathrm{a}$ & $6.71 \mathrm{~b}$ & $2.39 \mathrm{a}$ & 7.80 \\
Proteins & $57.61 \mathrm{a}$ & $54.34 \mathrm{~b}$ & $53.24 \mathrm{c}$ & 57.60 \\
Fixed mineral residue & $16.60 \mathrm{~b}$ & $14.96 \mathrm{c}$ & $19.12 \mathrm{a}$ & 15.10 \\
Total carbohydrates & $16.87 \mathrm{a}$ & $17.17 \mathrm{a}$ & $15.45 \mathrm{a}$ & - \\
Sodium & & &
\end{tabular}

${ }^{*}$ Results expressed on a wet basis; ${ }^{* *}$ Same letters in the same row do not differ by Tukey test at 5\%; (-) Data not available; Values are mean \pm SD $(n=6)$. 
Table 2. Nutritional composition determined analytically in servings ${ }^{\star}$ of beef bouillon cubes and the values displayed on product labels.

\begin{tabular}{|c|c|c|c|c|c|}
\hline Brand/Lot & $\begin{array}{c}\text { Proteins } \\
\left(\mathrm{g} / \text { serving }^{\star}\right)\end{array}$ & $\begin{array}{c}\text { Lipids } \\
\text { (g/serving*) }\end{array}$ & $\begin{array}{l}\text { Carbohydrates } \\
\text { (g/serving*) }\end{array}$ & $\begin{array}{c}\text { Sodium } \\
\left(\mathrm{mg} / \text { serving }^{*}\right)\end{array}$ & $\begin{array}{l}\text { TEV } \\
(\mathrm{kcal})\end{array}$ \\
\hline \multicolumn{6}{|l|}{ Brand A1 } \\
\hline 1 & 0.09 & 0.93 & 0.76 & 697.30 & 11.46 \\
\hline 2 & 0.07 & 0.95 & 0.78 & 885.88 & 11.69 \\
\hline 3 & 0.07 & 0.94 & 0.83 & 821.16 & 11.81 \\
\hline Mean & $0.08 \mathrm{~b}$ & $0.94 \mathrm{~b}$ & $0.79 \mathrm{a}$ & $801.44 a$ & $11.64 \mathrm{~b}$ \\
\hline SD & 0.01 & 0.01 & 0.04 & 95.82 & 0.19 \\
\hline Label $^{* *}$ & - & 1.00 & 0.90 & $1,025.00$ & 12.00 \\
\hline \multicolumn{6}{|l|}{ Brand A2 } \\
\hline 1 & 0.31 & 0.96 & 0.73 & 767.36 & 11.55 \\
\hline 2 & 0.36 & 0.95 & 0.69 & 838.85 & 11.28 \\
\hline 3 & 0.30 & 0.95 & 0.71 & 840.39 & 11.41 \\
\hline Mean & $0.32 \mathrm{a}$ & $0.95 b$ & $0.71 \mathrm{c}$ & $815.54 \mathrm{a}$ & $11.41 \mathrm{~b}$ \\
\hline SD & 0.03 & 0.01 & 0.02 & 41.73 & 0.13 \\
\hline Label $^{\star *}$ & 0.00 & 1.00 & 0.20 & 971.00 & 12.00 \\
\hline \multicolumn{6}{|l|}{ Brand A3 } \\
\hline 1 & 0.08 & 1.04 & 1.03 & 794.06 & 13.44 \\
\hline 2 & 0.14 & 1.04 & 1.01 & 743.66 & 13.44 \\
\hline 3 & 0.16 & 1.03 & 0.97 & 737.76 & 13.11 \\
\hline Mean & $0.13 b$ & $1.04 \mathrm{a}$ & $1.00 \mathrm{a}$ & $758.49 a$ & $13.33 \mathrm{a}$ \\
\hline SD & 0.04 & 0.01 & 0.03 & 30.94 & 0.19 \\
\hline Label $^{* *}$ & 0.00 & 1.20 & 1.00 & 993.00 & 15.00 \\
\hline Deviation $(\mathrm{X})^{\star * *}$ & 0.13 & 0.05 & 0.31 & 29.71 & 1.69 \\
\hline
\end{tabular}

cardiovascular disease in some individuals (Garfinkle, 2017; Mancia et al., 2017). The World Health Organization (2013) recommends a $30 \%$ reduction in sodium intake worldwide until 2025 and a mean sodium intake target of less than $2 \mathrm{~g} /$ day, enough to meet human needs both for both sodium and iodine. This nutrient is added by industries to foods to improve taste, ensure food safety and maintain the texture and structure of products (Brasil, 2006; 2011). In 2011, in Brazil, several agencies have signed a Statement of Commitment in order to monitor and reduce the sodium content in processed foods, specifying the term for compliance at the end of 2013. This statement included breakfast cereals, bouillon cubes, bouillon powder, margarine, pasta seasoning and spices for rice (Brasil, 2011). In general, all cube bouillon samples, regardless of the lot, reached the limit of no more than $1,100 \mathrm{mg}$ of sodium per serving as stipulated in the Statement of Commitment signed between the Brazilian Ministry of Health and food producer associations.

The results for protein, fat, total carbohydrates, sodium and total energy in beef bouillon cubes diverged from the contents reported on the labels, but only sodium exceeded the margin of error of $20 \%$ allowed by the RDC Resolution no. 360/2003 of the National Health Surveillance Agency (Brasil, 2003b). Incorrect information regarding the sodium content in the label hurts the consumer's right regarding the precise information of the food contents. However, the mistake can be mitigated when the variation is less than $20 \%$. In this case, this is desirable.

\section{CONCLUSIONS}

The beef bouillon cubes analyzed showed a low moisture content and high levels of lipids and fixed mineral residue. When compared to the data reported on their labels, all the parameters were in smaller amounts than the ones declared in all analyzed brands. However, in one of the samples, there was a high discrepancy between the levels of carbohydrates: nearly four times higher. We believe that there may be a problem in the labeling of this product, since the results are very close to those found in other analyzed brands.

Although the manufacturers of these products have reached the limit of no more than $1,100 \mathrm{mg}$ of sodium per serving as stipulated in the Statement of Commitment signed between the Brazilian Ministry of Health and the food producer associations, the average sodium content found in the samples is still high, corresponding on an average to $40 \%$ of the recommended daily intake. This is worrisome because food prepared with this ingredient is usually eaten alongside other foods containing salt in their composition. The results also reinforce the importance of the consumer to verify the nutritional composition informed in the product labels so that they are able to identify foods with a lower sodium content within a same product category or between different categories. 


\section{Acknowledgements}

The authors would like to thank the Coordination for the Improvement of Higher Education Personnel (CAPES), the Scientific and Technological Development Support Foundation of Ceará (FUNCAP), and the Federal Institute of Education, Science and Technology of Ceará (IFCE), which made this work possible.

\section{References}

Association of Official Analytical Chemists - AOAC. (2005). Official methods of analysis of The Association of Official Analytical Chemists (18th ed.). Gaithersburg: AOAC.

Atwater, W. O. (1910). Principles of nutrition and nutritive value of food (Farmers' Bulletin, 142). Washington: Government Printing Office, US Department of Agriculture.

Brasil, Ministério da Saúde. Agência Nacional de Vigilância Sanitária. (2003a, dezembro 23). Aprova o regulamento técnico de porções de alimentos embalados para fins de rotulagem nutricional (Resolução RDC $\mathrm{n}^{\circ} 359$, de 23 de dezembro de 2003). Diário Oficial [da] República Federativa do Brasil, seção 1.

Brasil, Ministério da Saúde. Agência Nacional de Vigilância Sanitária. (2003b, dezembro 23). Dispõe sobre regulamento técnico sobre rotulagem nutricional de alimentos embalados (Resolução RDC 360 de 23 de dezembro de 2003). Diário Oficial [da] República Federativa do Brasil, seção 1 .

Brasil, Ministério da Saúde. Secretaria de Atenção à Saúde. (2006). Guia alimentar para a população brasileira: promovendo a alimentação saudável. Brasília: Coordenação geral da política de alimentação e nutrição.

Brasil. Ministério da Saúde (2011). Termo de Compromisso entre o MS, ABIA, ABIMA, ABITRIGO, ABIP, com a finalidade de estabelecer metas nacionais para a redução do teor de sódio em alimentos processados no Brasil (Termo de Compromisso n ${ }^{\circ}$ 004/2011). Diário Oficial [da] República Federativa do Brasil, seção 3.

Câmara, M. C. C., Marinho, C. L. C., Guilam, C. M., \& Braga, A. M. C. B. (2008). A produção acadêmica sobre a rotulagem de alimentos no Brasil. Revista Panamericana de Salud Pública, 23(1), 52-58. http:// dx.doi.org/10.1590/S1020-49892008000100007. PMid:18291073.

Garfinkle, M. A. (2017). Salt and essential hypertension: pathophysiology and implications for treatment. Journal of the American Society of Hypertension, 11(6), 385-391. http://dx.doi.org/10.1016/j. jash.2017.04.006. PMid:28479261.

Guimarães, C. P., \& Lanfer-Marquez, U. M. (2002). Composição química de tabletes de caldo de carne: nitrogênio proteico, não proteico e fenilalanina. Food Science and Technology (Campinas), 22(3), 308313. http://dx.doi.org/10.1590/S0101-20612002000300019.

Gupta, S., \& Bongers, P. (2011). Bouillon cube process design by applying product driven process synthesis. Chemical Engineering and Processing: Process Intensification, 50(1), 9-15. http://dx.doi. org/10.1016/j.cep.2010.10.008.
Karšulínová, L., Folprechtová, B., Doležal, M., Dostálová, J., \& Velíšek, J. (2007). Analysis of the lipid fractions of coffee creamers, cream aerosols, and bouillon cubes for their health risk associated constituents. Czech Journal of Food Sciences, 25(5), 257-264. http:// dx.doi.org/10.17221/679-CJFS.

Kim, H., Lee, J., \& Kim, B. (2017). Development of an initial lexicon for and impact of forms (cube, liquid, powder) on chicken stock and comparison to consumer acceptance. Journal of Sensory Studies, 32(2), 1-10. http://dx.doi.org/10.1111/joss.12251.

Lobanco, C. M., Vedovato, G. M., Cano, C. B., \& Bastos, D. H. (2009). Fidedignidade de rótulos de alimentos comercializados no município de São Paulo, SP. Revista de Saude Publica, 43(3), 499-505. http:// dx.doi.org/10.1590/S0034-89102009000300014. PMid:19347174.

Malavolta, E., Vitti, C. G., \& Oliveira, S. A. (1997). Avaliação do estado nutricional das plantas: princípios e aplicações. Piracicaba: POTAFOS.

Mancia, G., Oparil, S., Whelton, P. K., McKee, M., Dominiczak, A., Luft, F. C., AlHabib, K., Lanas, F., Damasceno, A., Prabhakaran, D., La Torre, G., Weber, M., O'Donnell, M., Smith, S. C., \& Narula, J. (2017). The technical report on sodium intake and cardiovascular disease in low-and middle-income countries by the joint working group of the World Heart Federation, the European Society of Hypertension and the European Public Health Association. European Heart Journal, 38(10), 712-719. PMid:28110297.

Miller, G. L. (1959). Use of dinitrosalicylic acid reagent for determination of reducing sugar. Analytical Chemistry, 31(3), 426-428. http://dx.doi. org/10.1021/ac60147a030.

Núcleo de Estudos e Pesquisas em Alimentação - NEPA. (2011). Tabela brasileira de composição de alimentos (4. ed., Revisada e Ampliada). Campinas: Universidade Estadual de Campinas; 2011. Retrieved from http://www.unicamp.br/nepa/taco/contar/taco_4_edicao_ampliada_e_ revisada.pdf?arquivo=taco_4_versao_ampliada_e_revisada.pdf

Raw Materials Research and Development Council - RMRDC. (2003, December). Multi-disciplinary committee report of the techno-economic survey offood, beverage and tobacco sector - 4 Update. Nigeria: Federal Ministry of Science and Technology Abuja.

Rodrigues, É. D. F., Pantoja, L. D. A., Soares, M. B., Nelson, D. L., \& Santos, A. S. D. (2016). Development of bouillon cubes from souari nut pulp: formulation and physicochemical and sensorial evaluations. Brazilian Journal of Food Technology, 19(0), 1-8. http:// dx.doi.org/10.1590/1981-6723.5415.

Statsoft. (2007). Statistica for Windows: computer programa manual. Version 7.0. Tulsa: Statsoft Inc.

Visioli, F., \& Galli, C. (1998). Olive oil phenols and their potential effects on human health. Journal of Agricultural and Food Chemistry, 46(10), 4292-4296. http://dx.doi.org/10.1021/jf980049c.

World Health Organization - WHO. (2013). Follow-up to the political declaration of the high-level meeting of the general assembly on the prevention and control of non-communicable diseases. In: Sixty-Sixth World Health Assembly: 66 (pp. 16-21). Geneva: WHO. Retrieved from http://www.who.int/ncds/governance/2013-resolution-whichadopted-GAP.pdf 